\title{
Pectobacterium and Dickeya species detected in vegetables in Northern Ireland
}

\author{
Maja A. Zaczek-Moczydłowska • Colin C. Fleming • \\ Gillian K. Young • Katrina Campbell • \\ Richard O Hanlon
}

Accepted: 22 January 2019/Published online: 7 February 2019

(C) The Authors 2019 carrots led to the detection of $P$. carotovorum and Dickeya sp. This is the first study to provide knowledge about Pectobacterium and Dickeya spp. diversity causing soft rot of vegetables in Northern Ireland confirmed by real-time PCR and DNA sequences. This is also the first report of the detection of $D$. aquatica from a source other than water.

Keywords Pectobacterium - Dickeya . Soft rot Enterobacteriaceae $\cdot \mathrm{PCR}$ detection $\cdot r e c$ A sequencing

\section{Introduction}

Soft rot Pectobacteriaceae (SRP; formerly soft rot Enterobacteriaceae) include the genera Pectobacterium and Dickeya (Adeolu et al. 2016) and are widespread globally (Bhat et al. 2010; Mansfield et al. 2012). SRP causes high loses particularly in potato production, estimated in the Netherlands at up to $€ 30$ million annually (Toth et al. 2011) with potential global losses of up to $30 \%$ (Agrios 2007) at an estimated cost of US\$50-100 million every year in vegetables, fruits and ornamental plants (Pérombelon and Kelman 1980; Pérombelon 2002; Ma et al. 2007).

Previously known as Erwinia species (Winslow et al. 1920), the taxonomic reclassifications based on genetic differences within this genus led to the recognition of the genus Pectobacterium (Hauben et al. 1998) which was later separated into Pectobacterium and Dickeya (Samson et al. 2005). Pectobacterium currently includes ten formally described species and three subspecies 
(Gardan et al. 2003; Nabhan et al. 2013; Khayi et al. 2016) with several recently described species including Pectobacterium polaris (Dees et al. 2017b), Pectobacterium peruviense (Waleron et al. 2017), Pectobacterium punjabense (Sarfraz et al. 2018), Pectobacterium zantedeschiae (Waleron et al. in press) and Candidatus Pectobacterium maceratum (Shirshikov et al. 2018) being proposed. The genus Dickeya currently includes eight species and two subspecies (Samson et al. 2005; Brady et al. 2012; Parkinson et al. 2014; van der Wolf et al. 2014; Tian et al. 2016). Recently, a number of reports have shown Dickeya solani and Pectobacterium carotovorum subsp. brasiliense to cause high losses in Western Europe (Nunes Leite et al. 2014; de Werra et al. 2015; Toth et al. 2011; van der Wolf et al. 2017). Moreover, several studies have confirmed that Pectobacterium atrosepticum and Pectobacterium carotovorum subsp. carotovorum are some of the predominant causes of soft rot and/or blackleg in temperate regions (de Boer et al. 2012; Dees et al. 2017a; Waleron et al. 2013; Elphistone 2016a, b). Pectobacterium atrosepticum is mainly associated with potato blackleg and soft rot in temperate climates (Pérombelon 2002; Skelsey et al. 2018; Oztruk et al. 2018) but its occurrence might not be limited to potato, as it has been isolated from other hosts such as sunflower (Bastas et al. 2009) and pepper (Stommel et al. 1996). Pectobacterium carotovorum subsp. carotovorum has a broad host range, including but not limited to carrots, potatoes, cabbage, lettuce and onions across a number of climatic zones including Europe (Peltzer and Sivasithamparam 1985; Waleron et al. 2002; Pérombelon 2002; Gardan et al. 2003; Toth et al. 2003; Crowhurst and Wright 1998; de Haan et al. 2008; van der Merwe et al. 2010; Cariddi and Sanzani 2013; Onkendi and Moleleki 2014; Moretti et al. 2016; Dees et al. 2017a; Naas et al. 2018; Oztruk et al. 2018). Dickeya spp. have been confirmed as the most destructive pathogens in terms of losses in Switzerland (Toth et al. 2011; Golanowska and Łojkowska 2016). The species Dickeya dianthicola is recommended for regulation as a pest in the European and Mediterranean Plant Protection Organisation (EPPO) (A2 pathogen; EPPO 2017). Therefore several countries have introduced national legislation to prevent the introduction of this species. In the UK, both Scotland and Northern Ireland have a 'nil' tolerance for Dickeya spp., and Northern Ireland has a 'nil' tolerance for Pectobacterium spp. (termed "blackleg") in pre-basic seed potatoes production and up to $1 \%$ tolerance for Pectobacterium spp. in basic seed potatoes (Anonymous 2010; Anonymous 2016).

The island of Ireland (Ireland and Northern Ireland) has a favourable climate for potato growing, with moderate temperatures, high humidity and a geographic location influenced by the Atlantic Ocean which restricts aphid populations and results in low levels of aphid-borne potato viruses (Proudfoot and Mccallum 1961). However, these conditions are also optimal for the spread of SRP (Pérombelon 2002). In Northern Ireland, potato is the second most important field crop after cereals (barley, wheat and oats) valued in 2017 to $£ 23.8$ million (Anonymous 2017). Overall, little is known about the diversity of SRP populations in Northern Ireland. Early observations indicated that blackleg disease may have been present in potato crops in Ireland as early as 1845 (Bourke 1966), with the first isolation of the putative organism Pectobacterium atrosepticum (listed as Bacillus melanogenes) by Pethybridge and Murphy (1911). Pectobacterium atrosepticum (recorded as Erwinia carotovora subsp. atroseptica) and P. carotovorum (recorded as Erwinia carotovora) have been recorded in Northern Ireland (Logan 1968; O'Neil and Logan 1975; Hossain 1986). Pectobacterium atrosepticum causing blackleg was listed as a large threat potato production in Northern Ireland by Logan et al. 1987. The presence of other species and subspecies of Pectobacterium in potato and other vegetables is unknown. Given the significance of potato and other vegetable (carrot and onion) production in Northern Ireland, with the total annual output of up to $£ 42.5$ million (Anonymous 2017), and the potential losses from SRP, the aim of this study was to investigate the diversity of Pectobacterium present in Northern Ireland and provide the first up to date report for over 30 years.

\section{Materials and methods}

Sample collection

Symptomatic and asymptomatic potato samples, and water samples from potato processing facilities are submitted to the Agri-Food and Biosciences Institute (AFBI) for detection of plant pests and pathogens on behalf of the Department of Agriculture, Environment and Rural Affairs (DAERA). These statutory samples are tested for the regulated bacterial potato pathogens Clavibacter michiganensis subsp. sepedonicus, Ralstonia 
solanacearum, and Dickeya spp. During the years 20052017, 3456 statutory samples of symptomatic and asymptomatic material were tested for $C$. michiganensis subsp. sepedonicus, $R$. solanacearum with samples also tested for Dickeya spp. from 2010 onwards.

To investigate Pectobacterium diversity in Northern Ireland, in the years 2015 and 2016 a total 454 of these samples showing soft rot or blackleg symptoms were further analysed as part of this research. To supplement this data, a field survey was carried out in 2017 in four locations in Co. Londonderry and Co. Down in Northern Ireland. During this survey, potato samples with symptoms of blackleg were collected and tested for the presence of SRP. Carrots and onions grown in Northern Ireland were sourced from local growers and/or from local shops in Co. Down, Co. Antrim, Co. Armagh and Co. Londonderry and were also tested for SRP.

Preparation of samples from asymptomatic potato tuber extracts

Prior to analysis for detection of Dickeya spp. from statutory samples by real-time PCR with the specific primers ECH and/or SOL, DIC (Pritchard et al. 2013), potato extracts were prepared using the methodology adapted from Commission Directive 2006/63/CE for the control of $R$. solanacearum (Anonymous 2006). In brief, two hundred cores $(5 \mathrm{~mm})$ obtained from the stolon end of potato were transferred to a macerating container and $40 \mathrm{~mL}$ of macerating buffer containing $\mathrm{Na}_{2} \mathrm{HPO}_{4}(4.26 \mathrm{~g}), \mathrm{KH}_{2} \mathrm{PO}_{4}(2.72 \mathrm{~g})$ per litre was added, followed by 2 min of maceration at low speed in a homogeniser. Macerated samples were filter through a single layer muslin into a beaker. The filtrate was transferred into a centrifuge tube and centrifuged (200 rpm, $4-10{ }^{\circ} \mathrm{C}$ ) for $10 \mathrm{~min}$. The obtained supernatant was poured into a clean centrifuge tube and centrifuged $\left(11,000 \mathrm{rpm}, 4-10^{\circ} \mathrm{C}\right)$ for $15 \mathrm{~min}$. The supernatant was discarded and the pellet suspended in $1.5 \mathrm{~mL}$ of pellet buffer containing $\mathrm{Na}_{2} \mathrm{HPO}_{4}(2.7 \mathrm{~g}), \mathrm{NaH}_{2} \mathrm{PO}_{4}$ $(0.4 \mathrm{~g})$ per litre. The sample was then enriched in pectate enrichment medium (PEM) in compact workstations for anaerobic and microaerophilic conditions for detection of Dickeya spp. for $48 \mathrm{~h}$ at $37^{\circ} \mathrm{C}$ (Anonymous 2010c).

Isolation of SRP strains from symptomatic samples

A modified double layer crystal violet pectate (CVP) media was used for detection and isolation of SRP. The agar was prepared using a modification of the method previously reported by Bdliya et al. (2004) which excludes bromthymol blue and 2,3,5 triphenylterrazolium chloride and with the inclusion of Dipecta (Agdia-Bioford) as the pectate source. For the rotting vegetables, samples were taken from the macerated tissues about $1 \mathrm{~cm}$ inside the surface using a sterile scalpel, suspended in $10 \mathrm{ml}$ of sterile water and vortexed for $5 \mathrm{~min}$ at $10 \mathrm{x}$ speed. A total of $100 \mu \mathrm{l}$ of plant material extract was streaked onto a CVP agar plate, followed by streaking the same hockey stick on five subsequent plates - thus providing a dilution series of plates. The plates were incubated for $48 \mathrm{~h}$ at $28^{\circ} \mathrm{C}$ for detection of Pectobacterium spp. and for $48 \mathrm{~h}$ at $37^{\circ} \mathrm{C}$ for detection of Dickeya spp. from statutory samples after which they were assessed to determine the number of cavity or pit forming bacterial colonies of pink to red colour and with rod-shaped cells. Bacterial colonies that matched these characteristics were aseptically streaked onto nutrient agar (NA) plates (Oxoid) and incubated for $48 \mathrm{~h}$ at $25^{\circ} \mathrm{C}$ to obtain pure cultures.

\section{DNA extraction and molecular detection}

For DNA extraction, bacterial cultures grown on NA were transferred into the lysis buffer of the Maxwell®16 cell LEV DNA Purification kit (Promega) following the manufacturer's instructions. A number of samples of extracts of asymptomatic potato were also lysed using the procedure above. Bacterial DNA were purified for 30-45 min using a Maxwell DNA Magnetic Particle Processor MX 3031 (Promega) using the cell purification program. DNA extracts were quantified using a NanoDrop 2000 (Thermo Scientific), and the concentrations of bacterial DNA extracts adjusted to between 10 and 20 ng. Purified bacterial DNA were stored at $-20{ }^{\circ} \mathrm{C}$ until further analysis.

Real-time PCR was carried out using primers PEC, ECA, ECH, DIC and SOL (Pritchard et al. 2013). The real-time PCR assay was performed in a $12.5 \mu \mathrm{L}$ reaction mixture comprising GoTaq Probe qPCR (QuantiNova) $(6.25 \mu \mathrm{L})$, genomic DNA from bacterial culture ca. $10-20 \mathrm{ng}(0.5 \mu \mathrm{L})$, primers $(5 \mu \mathrm{M} 0.375 \mu \mathrm{L})$, Nuclease-free $\mathrm{H}_{2} \mathrm{O}$ (Qiagen) $(4.74 \mu \mathrm{L})$. Amplification conditions were as follows: DNA was initially denatured at $95{ }^{\circ} \mathrm{C}$ for $2 \mathrm{~min}$, followed by 40 cycles of denaturation $95{ }^{\circ} \mathrm{C}$ for $5 \mathrm{~s}$, annealing at $50{ }^{\circ} \mathrm{C}$ for $5 \mathrm{~s}$. PCR was carried out using a Prime Pro 48 real-time qPCR system 
(Techne). For real-time PCR, positive results were regarded at critical threshold $\left(C_{t}\right)$ values $<36$.

Conventional PCR was performed in a $12.5 \mu \mathrm{L}$ reaction mixture comprising GoTaq PCR Mastermix $(6.25 \mu \mathrm{L})$, genomic DNA from bacterial culture ca.10$20 \mathrm{ng}(2.5 \mu \mathrm{L})$, primers Y1\&Y2 (Darasse et al. 1994), Y45\&Y46 (Frechon et al. 1998) $(10 \mu \mathrm{M} 0.50 \mu \mathrm{L})$, Nuclease- free $\mathrm{H}_{2} \mathrm{O}$ (Qiagen) $(2.75 \mu \mathrm{L})$. Amplification conditions were as follows: DNA was initially denatured at $95{ }^{\circ} \mathrm{C}$ for $5 \mathrm{~min}$, followed by 37 cycles of denaturation $95^{\circ} \mathrm{C}$ for $60 \mathrm{~s}$, annealing at $67^{\circ} \mathrm{C}$ for $60 \mathrm{~s}$, and polymerisation at $72{ }^{\circ} \mathrm{C}$ for $60 \mathrm{~s}$ and finally 1 cycle at $72{ }^{\circ} \mathrm{C}$ for $10 \mathrm{~min}$. PCR was carried out using a Standard Life Pro Thermocycler (Bioer). The obtained PCR products were visualised using QIAxcel Advanced System (Qiagen).

Amplification of the RecA multifunctional protein from the bacterial DNA extracts obtained was performed using primers EC-RecAR \& EC-RecAF (Waleron et al. 2002). DNA amplification was performed in a $12.5 \mu \mathrm{L}$ reaction mixture comprising GoTaq PCR Mastermix $(6.25 \mu \mathrm{L})$, genomic DNA from bacterial culture ca. $10-20 \mathrm{ng}(0.5 \mu \mathrm{L})$, primers $(10 \mu \mathrm{M}$ $0.50 \mu \mathrm{L})$, Nuclease- free $\mathrm{H}_{2} \mathrm{O}$ (Qiagen) $(4.75 \mu \mathrm{L})$. Amplification conditions were as follows: DNA was initially denatured at $95^{\circ} \mathrm{C}$ for $5 \mathrm{~min}$, followed by 32 cycles of denaturation $94^{\circ} \mathrm{C}$ for $60 \mathrm{~s}$, annealing at $47^{\circ} \mathrm{C}$ for $60 \mathrm{~s}$, and extension at $72{ }^{\circ} \mathrm{C}$ for $5 \mathrm{~min}$ and the final extension at $72{ }^{\circ} \mathrm{C}$ for $5 \mathrm{~min}$. The procedure was carried out using a Life Pro Thermocycler (Bioer) RecA program for $2 \mathrm{~h}$ $42 \mathrm{~min}$. The obtained PCR products were visualised using QIAxcel Advanced System (Qiagen). DNA extracts that amplified with RecA primers, and had a PCR product of 700-1000 bp were sent for sequencing.

Phylogenetic analysis and pairwise comparison

Sequencing of PCR amplicons was performed by a commercial sequencing service at Queens University Belfast Genomics Core Technology Unit using an Applied Biosystems 3730 (Thermo Fisher Scientific). The obtained sequences of the forward and reverse strands were assembled, aligned and trimmed using Geneious version 10.1.3 (Biomatters) software and compared using Basic Local Alignment Search Tool (BLAST) analysis with sequences available in GenBank (Altschul et al. 1990). The obtained sequences of Pectobacterium and Dickeya spp. were deposited in GenBank under following accession numbers:
MH290883, MH315943, MH329871-MH329878, MH346375 - MH346385, MH481716 - MH481722, MH484268, MH688057 - MH688058, MK305814 and MK305815.

Obtained sequences (Table 1) were analysed for the species within the genus Pectobacterium and Dickeya spp. from across Northern Ireland by further phylogenetic analysis. Multiple alignment of the sequences was performed using CLC Main Workbench 8.0 (Qiagen) with reference sequences obtained from GenBank (National Centre of Biotechnology Information) i.e. P. atrosepticum (AY264783, KF704802), P. c. subsp. carotovorum (AY264799, AY264798, KY067403, MF314822) P. c. subsp. brasieliense (KP762587, KP762588), P. c. subsp. odoriferum (KF704811, KF704807), P. wasabiae (KC584992, KC584995 and AY264796), D. aquatica (JX273703), D. zeae (KY817909) and Candidatus P. maceratum (MK024779). Phylogenetic trees were generated using the Neighbor-joining method (Kimura 1980) using CLC Main Workbench 8.0 software. Bootstrapping was executed with 1000 replications. The bootstrap values $<50 \%$ were excluded.

The multiple alignments were tested on five different models prior to construction of the tree to find the bestfit model for the final phylogenetic tree by the hierarchical likelihood ratio test (hLRT) and Bayesian Information Criterion (BIC). Both tests showed Kimura 80 as the best-fit model, thus a neighbour-joining tree was constructed based on that model (Fig. 1). The pairwise comparison of obtained multiple alignment was constructed (Tamura et al. 2004) based on percentage identity of Northern Irish strains with reference sequences obtained from GenBank using CLC Main Workbench 8.0 software.

\section{Results}

Statutory samples from asymptomatic and symptomatic potato tubers in Northern Ireland for Dickeya spp.

More than 3456 potato samples were tested for regulated bacterial pathogens between the years 2005-2017, 1891 originating in Northern Ireland and 1565 originating from other countries. Of these, Dickeya spp. were not detected in potato samples originating in Northern Ireland. Clavibacter michiganensis subsp. sepedonicus and $R$. solanacearum were not detected in any samples (Table 2). 
Table 1 Details of Pectobacterium and Dickeya spp. isolated from potato and carrots in Northern Ireland identified by sequences of the recA gene fragment use in this study

\begin{tabular}{|c|c|c|c|c|c|c|}
\hline Number & Accession number & Strain & Species $^{\mathrm{a}}$ & Year of isolation & Location $^{\mathrm{b}}$ & Host \\
\hline 1 & MH329877 & B2 & P. atrosepticum & 2017 & Co. Antrim & potato stem \\
\hline 2 & MH346384 & F5 & P. atrosepticum & 2017 & Co. Armagh & potato tuber \\
\hline 3 & MH481719 & L1 & P. atrosepticum & 2017 & Co. L'derry & potato tuber \\
\hline 4 & MH484268 & $\mathrm{P} 14$ & P. atrosepticum & 2014 & unknown & potato \\
\hline 5 & MH481722 & P16 & P. atrosepticum & 2014 & unknown & potato \\
\hline 6 & MH329878 & P1B & P. atrosepticum & 2016 & Co. Antrim & potato tuber \\
\hline 7 & MH481716 & $\mathrm{P} 2 \mathrm{~A}$ & P. atrosepticum & 2016 & Co. Antrim & potato tuber \\
\hline 8 & MH481717 & $\mathrm{P} 2 \mathrm{~B}$ & P. atrosepticum & 2016 & Co. Antrim & potato tuber \\
\hline 9 & MH290883 & $\mathrm{P} 4 \mathrm{~A}$ & P. atrosepticum & 2016 & Co. Antrim & potato tuber \\
\hline 10 & MH346385 & P4B & P. atrosepticum & 2016 & Co. Antrim & potato tuber \\
\hline 11 & MH481718 & $\mathrm{S} 11$ & P. atrosepticum & 2017 & Co. L'derry & potato tuber \\
\hline 12 & MH346378 & $\mathrm{S} 12$ & P. atrosepticum & 2017 & Co. L'derry & potato tuber \\
\hline 13 & MH346379 & S15 & P. atrosepticum & 2017 & Co. L'derry & potato tuber \\
\hline 14 & MH346380 & $\mathrm{S} 16$ & P. atrosepticum & 2017 & Co. L'derry & potato tuber \\
\hline 15 & MH346383 & $\mathrm{S} 18$ & P. atrosepticum & 2017 & Co. L'derry & potato tuber \\
\hline 16 & MH346381 & $\mathrm{S} 21$ & P. atrosepticum & 2017 & Co. L'derry & potato tuber \\
\hline 17 & MH481720 & $\mathrm{S} 24$ & P. atrosepticum & 2017 & Co. L'derry & potato tuber \\
\hline 18 & MH346382 & S26 & P. atrosepticum & 2017 & Co. L'derry & potato tuber \\
\hline 19 & MH481721 & S27 & P. atrosepticum & 2017 & Co. L'derry & potato tuber \\
\hline 20 & MH346376 & $\mathrm{S} 3$ & P. atrosepticum & 2017 & Co. L'derry & potato tuber \\
\hline 21 & MH346377 & S4 & P. atrosepticum & 2017 & Co. L'derry & potato tuber \\
\hline 22 & MH346375 & S5 & P. atrosepticum & 2017 & Co. L'derry & potato tuber \\
\hline 23 & MH329871 & $\mathrm{Ca} 1 \mathrm{~B}$ & P. c. subsp. carotovorum & 2016 & Co. Down & carrot \\
\hline 24 & MH329872 & $\mathrm{Ca} 2 \mathrm{~A}$ & P. c. subsp. carotovorum & 2016 & Co. Down & carrot \\
\hline 25 & MH329873 & $\mathrm{Ca} 2 \mathrm{~B}$ & P. c. subsp. carotovorum & 2016 & Co. Down & carrot \\
\hline 26 & MH315943 & D0346 & P. carotovorum & 2016 & Co. Down & carrot \\
\hline 27 & MH329875 & D0347 & P. carotovorum & 2016 & Co. Down & carrot \\
\hline 28 & MH329876 & D0349 & P. c. subsp. carotovorum & 2016 & Co. Down & carrot \\
\hline 29 & MH329874 & D0348 & P. carotovorum & 2016 & Co. Down & carrot \\
\hline 30 & MH688058 & $\mathrm{Ca} 3 \mathrm{~A}$ & D. aquatica & 2016 & Co. Down & carrot \\
\hline 31 & MH688057 & $\mathrm{Ca} 3 \mathrm{~B}$ & D. aquatica & 2016 & Co. Down & carrot \\
\hline 32 & MK305814 & SR22 & P. c. subsp. carotovorum & 2014 & unknown & potato tuber \\
\hline 33 & MK305815 & $\mathrm{C} 2558$ & P. c. subsp. carotovorum & 2015 & Co. Antrim & potato tuber \\
\hline
\end{tabular}

${ }^{a}$ Identity based on phylogenetic analysis (Kimura 1980)

${ }^{\mathrm{b}}$ Counties in Northern Ireland, UK

Symptomatic vegetables samples in years 2015-2017 for Pectobacterium spp.

From 454 samples tested, 164 samples from potatoes, carrots and onions originated from Northern Ireland were tested in years 2015-2017, using real-time PCR, conventional PCR and DNA sequencing. From all samples, 164 were confirmed as members of the genera Pectobacterium or Dickeya (Table 3). Pectobacterium atrosepticum was identified in 101 samples collected from vegetables between 2015 and 2017 (Table 3). Over the three years of sampling, $P$. atrosepticum was the most frequent species isolated from potato (97), also three from carrots and one from onion were confirmed with real-time PCR. Pectobacterium carotovorum was confirmed from twelve samples (Table 3). In Co. Down this species was identified in $83 \%$ of samples collected from carrots and onion, and in Co. Antrim 17\% from 


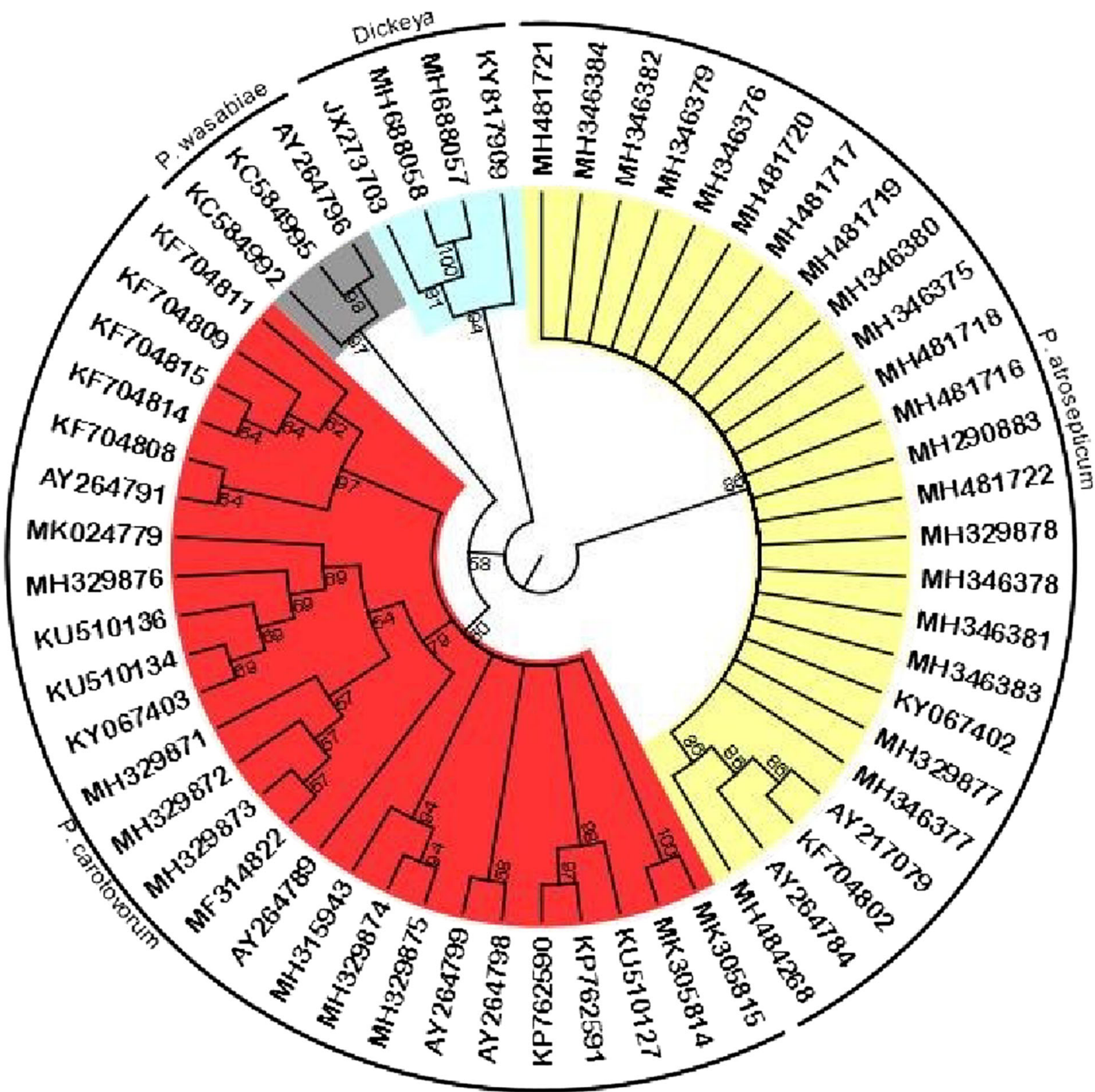

Fig. 1 The consensus of maximum likelihood phylogeny by neighbour-joining method (Kimura 1980) based on the fragment of the recA gene. Pectobacterium spp. and Dickeya spp. sequences detected in Northern Ireland and obtained from GenBank followed

potatoes. A single Dickeya sp. was identified from a potato sample by real-time PCR, and two carrots strains were identified as similar to $D$. aquatica by phylogenetic analysis. Real time PCR testing for $P$. atrosepticum and other SRP of 34 DNA extracts from asymptomatic tubers originating in Northern Ireland in 2016 found that 29 were positive for SRP. by accession numbers. Bootstrap values after 1000 replicates are expressed as percentages. Clusters with Bootstrap values $<50 \%$ are collapsed. The strains identified as P. atrosepticum (yellow), P. carotovorum (red), P. wasabiae (grey) Dickeya spp. (blue)

Phylogenetic analysis

Phylogentic analysis was carried out on a panel of 33 strains (Table 1), previously identified by BLAST as P. atrosepticum (23), P. c. subsp. carotovorum (9), and D. paradisiaca (1). These strains grouped separately into three main clusters corresponding to $P$. atrosepticum, P. carotovorum and Dickeya spp. (Fig. 1). Pectobacterium 
Table 2 Details of potato samples tested as part of statutory surveys for ring rot, brown rot and Dickeya spp. in Northern Ireland. Note that ring rot and brown rot have been not detected in Northern Ireland

\begin{tabular}{|c|c|c|c|c|c|c|c|}
\hline \multirow[t]{2}{*}{ Year } & \multicolumn{2}{|c|}{ Number of samples } & \multicolumn{2}{|c|}{ Dickeya spp. } & \multicolumn{2}{|c|}{ Dickeya solani } & \multirow{2}{*}{$\begin{array}{l}\text { Clavibacter } \\
\text { michiganensis subsp. } \\
\text { sepedonicus and } \\
\text { R. solanacearum } \\
\text { total }\end{array}$} \\
\hline & $\mathrm{NI}^{\mathrm{a}}$ & Total $^{\mathrm{b}}$ & $\mathrm{NI}^{\mathrm{a}}$ & Total $^{\mathrm{b}}$ & $\mathrm{NI}^{\mathrm{a}}$ & Total $^{\mathrm{b}}$ & \\
\hline 2005 & 161 & 273 & $\mathrm{nt}$ & $\mathrm{nt}$ & $\mathrm{nt}$ & $\mathrm{nt}$ & 0 \\
\hline 2006 & 163 & 265 & $\mathrm{nt}$ & $\mathrm{nt}$ & $\mathrm{nt}$ & $\mathrm{nt}$ & 0 \\
\hline 2007 & 277 & 404 & $\mathrm{nt}$ & $\mathrm{nt}$ & $\mathrm{nt}$ & $\mathrm{nt}$ & 0 \\
\hline 2008 & 162 & 323 & $\mathrm{nt}$ & $\mathrm{nt}$ & nt & $\mathrm{nt}$ & 0 \\
\hline 2009 & 214 & 335 & $\mathrm{nt}$ & $\mathrm{nt}$ & $\mathrm{nt}$ & $\mathrm{nt}$ & 0 \\
\hline 2010 & 125 & 227 & 0 & 0 & 0 & 0 & 0 \\
\hline 2011 & 153 & 270 & 0 & 3 & 0 & 3 & 0 \\
\hline 2012 & 99 & 203 & 0 & 2 & 0 & 0 & 0 \\
\hline 2013 & 111 & 334 & 0 & 0 & 0 & 0 & 0 \\
\hline 2014 & 160 & 290 & 0 & 2 & 0 & 0 & 0 \\
\hline 2015 & 128 & 259 & 0 & 1 & 0 & 1 & 0 \\
\hline 2016 & 90 & 188 & 0 & 0 & 0 & 0 & 0 \\
\hline 2017 & 48 & 85 & 0 & 0 & 0 & 0 & 0 \\
\hline Total & 1891 & 3456 & $\mathbf{0}$ & 9 & $\mathbf{0}$ & 4 & $\mathbf{0}$ \\
\hline
\end{tabular}

nt- not tested

${ }^{\text {a }}$ Samples originated from Northern Ireland

${ }^{\mathrm{b}}$ Samples included Northern Irish stock and also imports

carotovorum grouped into four main clusters: three isolates from carrots with $P$. carotovorum subsp. carotovorum strain (MF314822) and one carrot isolate in separate cluster with new proposed species of Candidatus P. maceratum (MK024779). Furthermore, three of the Northern Irish strains isolated from carrots (D0346, D0347 and D0348) and two potato isolates grouped in a separate clusters. Northern Irish P. atrosepticum strains constituted the cluster with the most similar in BLAST analysis type of P. atrosepticum strain (KY067402) and one grouped in a separate sub-cluster with strains of type $P$. atrosepticum ( AY217079, AY264784 and KF704802). Two of the Northern Irish strains $\mathrm{Ca} 3 \mathrm{~A}$ and $\mathrm{Ca} 3 \mathrm{~B}$ were grouped with the type strain of D. aquatica (JX273703) and D. zeae (KY817909) in the Dickeya cluster of Pectobacterium spp. phylogeny (Fig.1).

\section{Discussion}

In recent years, an increasing number of studies have detected Dickeya spp. in potato production in Europe (Toth et al. 2011; Potrykus et al. 2016). However detection of Dickeya spp. in countries that have implemented control programmes and legislation, such as Scotland and Norway is mostly linked to imported plant material (Skelsey et al. 2016; Dees et al. 2017a). In this study, detections of Dickeya spp. from statutory potato samples in years 2005-2017 in Northern Ireland were very rare and always linked to imported plant material. Moreover, so far Dickeya spp. have not been detected from potato grown in Northern Ireland analysed as statutory samples. This work therefore focused on investigating the diversity of Pectobacterium spp. rather than Dickeya spp. and samples obtained from field survey were not enriched at temperatures higher than $28{ }^{\circ} \mathrm{C}$. As demonstrated by Potrykus et al. (2016), Pectobacterium spp. can overgrow Dickeya spp. during isolation at lower temperatures; however, Dickeya may have been present at low concentrations.

Two isolates from carrots in this study (Ca3A and Ca3B) showed high similarity to $D$. aquatica. Separate analysis has attributed these two Northern Irish strains to the SLC 2 clade defined by Parkinson et al. (2014) in the Dickeya cluster in a separate phylogeny of Dickeya spp. with a high bootstrapping value (Supplementary Fig. 1). 


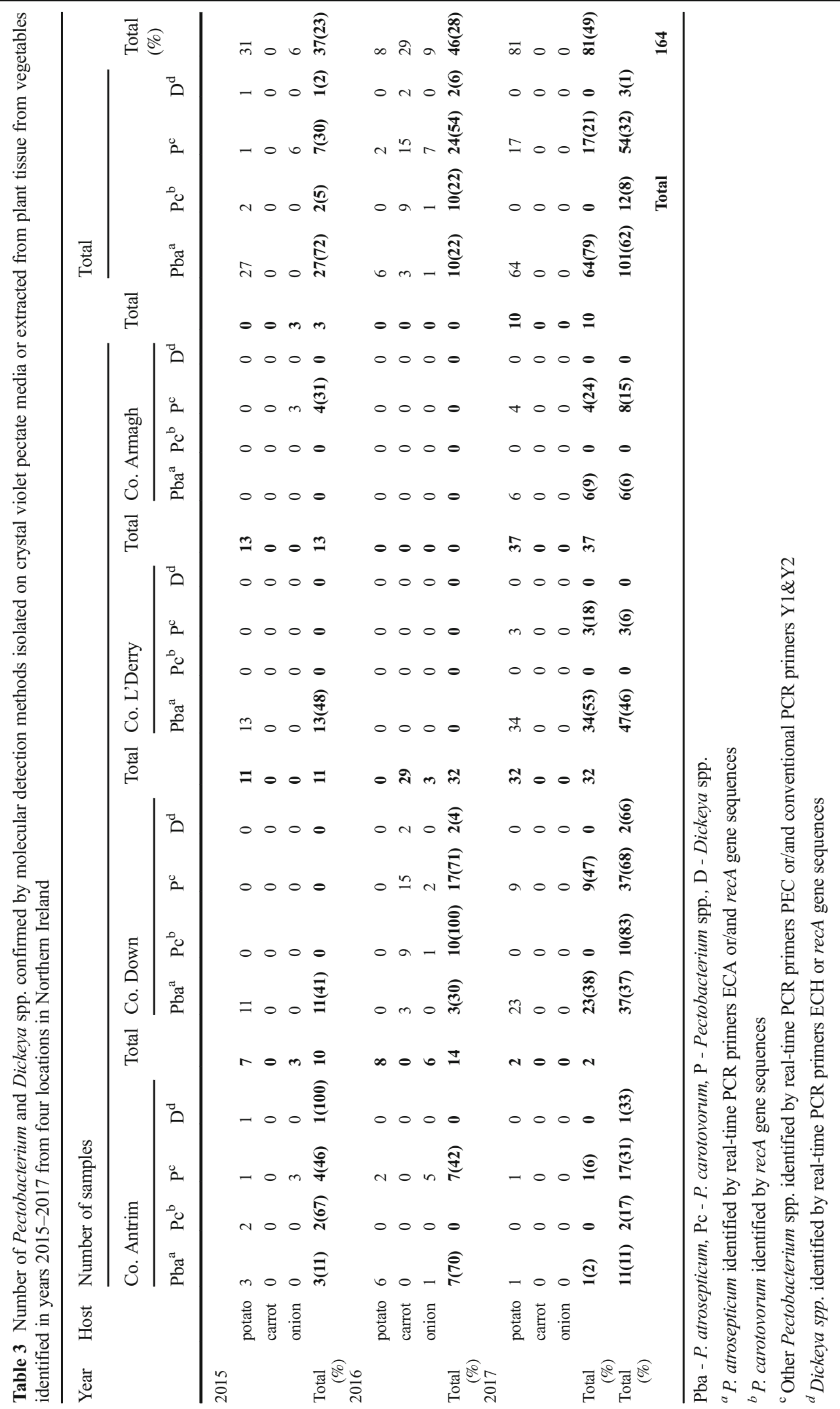


In 2008/09, a Dickeya sp. was isolated from water sources in Finland and Scotland which constituted a new clade SLC 2 which shows genetic differences to the known species of Dickeya (Laurila et al. 2008; Parkinson et al. 2009). Further work differentiated this new clade as a new species: D. aquatica (Parkinson et al. 2014). Research has shown that $D$. aquatica from water sources can cause rotting symptoms on potatoes in lab trials, but was not particularly virulent (Laurila et al. 2008,2010 ). This study is the first to isolate $D$. aquatica from diseased plants in the field. The presence of this pathogen in Northern Ireland and its relation to soft rot symptoms is not well understood. Although samples were collected from symptomatic carrots, the irrigation water source (a local river in Northern Ireland) cannot be excluded as the source of contamination which could allow transmission to other hosts and constitute a potential threat in potato production regions. This pathogen may also be a recent introduction. This is an area where further research is needed.

Pectobacterium atrosepticum was the most frequently detected Pectobacterium species detected during surveys 2015-2017. This study builds on previous studies in Northern Ireland (Logan 1963, 1968; O’Neil and Logan 1975; Hossain and Logan 1983; Rhodes and Logan 1986, 1987; Wastie et al. 1988; Gans et al. 1991) and Ireland (Buttimer et al. 2018). The native range of Pectobacterium atrosepticum is unknown, however, the pathogen has potentially been causing blackleg in Ireland for over 100 years (Pethybridge and Murphy 1911; Bourke 1966). Similar to our findings, $P$. atrosepticum was also the most frequently detected species in temperate climates including Canada (de Boer et al. 2012), Norway (Dees et al. 2017a) and UK (Elphistone 2016a, b; Toth et al. 2016). In Scotland, most blackleg disease was caused by $P$. atrosepticum (Skelsey et al. 2016; Toth et al. 2016). In a seed potato survey between 2013 and 2015 in England, Wales and Scotland, $P$. atrosepticum constituted $89.4 \%$ of all positive samples (Elphistone 2016a). In the UK, 17 haplotypes of $P$. atrosepticum have been confirmed to be present, including testing of some strains from the 1930s (Elphistone 2016b). Within P. atrosepticum isolates from Northern Ireland, high genetic homogeneity occurred with high identity values (99.06-100\% in pairwise comparison) to strain $P$. atrosepticum (KY067402) (Supplementary Fig. 2). High homogeneity of $P$. atrosepticum has also been found previously by Dees et al. (2017a).
Pectobacterium carotovorum subsp. carotovorum was recorded in Northern Ireland previously (Logan 1963, 1966, 1984; Hossain 1986). Logan (1963, 1966) reference to Erwinia carotovora and Erwinia carotovora pv. 'aroideae' probably correspond to Pectobacterium carotovorum subsp. carotovorum and not Pectobacterium aroidearum, which is primarily a pathogen of monocotyledonous hosts (Nabhan et al. 2013) and most recently has been detected from potatoes (Moretti et al. 2016) and zucchini (Moraes et al. 2017). However, its presence has not been confirmed in phylogenetic analysis (data not shown). The $P$. carotovorum population in Northern Ireland was more heterogeneous than $P$. atrosepticum based on serological grouping (Hossain 1986), and our phylogenetic analysis agrees with this findings. Two of isolates from potatoes (SR22 and C2558) and three of the carrot strains (D0346, D0347 and D0348) grouped separately from others $P$. c . subsp. carotovorum and formed a separate clusters in the phylogenetic analysis (Fig.1). Further research including the analysis of more gene regions is needed to clarify the identities of these SRP. The use of more molecular markers, and a wider range of isolation methods (e.g. different temperatures), as suggested by Czajkowski et al. (2015), would likely reveal the presence of more diversity within and between the species of SRP detected in Northern Ireland, and build upon the research presented here.

In previous studies, Pectobacterium carotovorum strains originated from Ireland and Scotland were reclassified by Nabhan et al. (2013) and Waleron et al. (2013) as $P$. wasabiae. In this study, P. wasabiae was not detected. One isolate (from rotting carrot D0349) (Fig. 1) clustered together with the type strain of the proposed novel taxon Candidatus P. maceratum. Recently, this new genomospecies was described based on genomic distinction of five $P$. c. subsp. carotovorum strains and showed the most genetic similarity to $P$. c c subsp. odoriferum (Shirshikov et al. 2018). Work performed by $\mathrm{Li}$ et al. (2018) through whole genome sequences of 84 isolates of SRP shows high genetic similarity of Candidatus P. maceratum to $P$. carotovorum and $P$. polaris. Moreover, through phylogenetic analysis this species clustered together with other $P$. $c$. subsp. carotovorum suggesting than more isolates in GenBank might belong to this morphospecies (Li et al. 2018). Thus far, one study provides the details showing virulence and pathogenicity of Candidatus P. maceratum on potato and bittersweet (Waleron et al. 2019), therefore its 
aggressiveness regarding other vegetables is not known. This study demonstrated that Pectobacterium spp. originating from Northern Ireland might be more diverse and further research should be performed to confirm occurrence of this new species.

The presence of three species of SRP in association with soft rot symptoms of vegetables as confirmed by PCR methods and phylogenetic analysis in Northern Ireland. This is the first published record of Pectobacterium and Dickeya spp. from Northern Ireland confirmed by DNA sequencing. This is the first study to document a confirmed isolation of $D$. aquatica from a symptomatic plant host in the field. Further research is needed to clarify the identity, distribution, and pathology of this taxa.

Acknowledgements The authors would like to thank the AFBI staff: B. Moreland, R. Swan, J. Pollock, J. Brazil, J. Morgan, J. Larkin, K. O'Neill, and F. McHardy for their assistance in the collection, preparation and analysis of the samples. The authors are grateful to the DAERA for provision of samples, field surveys and funding of this $\mathrm{PhD}$ project.

Funding The study was part of a PhD project funded by the DAERA in Northern Ireland $\mathrm{PhD}$ studentship.

Compliance with ethical standards The research does not involve human participants and/or animals.

Conflict of interest The authors declare that they have no conflict of interest.

Open Access This article is distributed under the terms of the Creative Commons Attribution 4.0 International License (http:// creativecommons.org/licenses/by/4.0/), which permits unrestricted use, distribution, and reproduction in any medium, provided you give appropriate credit to the original author(s) and the source, provide a link to the Creative Commons license, and indicate if changes were made.

\section{References}

Adeolu, M., Alnajar, S., Naushad, S., \& Gupta, S. R. (2016). Genome-based phylogeny and taxonomy of the 'Enterobacteriales': Proposal for Enterobacterales ord. nov. divided into the families Enterobacteriaceae, Erwiniaceae fam. nov., Pectobacteriaceae fam. nov., Yersiniaceae fam.nov., Hafniaceae fam. nov., Morganellaceae fam. nov., and Budviciaceae fam. nov. International Journal of Systematic and Evolutionary Microbiology, 66, 5575-5599.

Agrios, G. N. (2007). Bacterial soft rots (5th ed.). San Diego: Academic.
Altschul, S. F., Gish, W., Miller, W., Myers, E. W., \& Lipman, D. J. (1990). Basic local alignment search tool. Journal of Molecular Biology, 215, 403-410.

Anonymous (2006). Amending Annexes II to VII to Council Directive $98 / 57 /$ EC on the control of Ralstonia solanacearum (Smith) Yabuuchi et al. http://www.eppo. int/ABOUT_EPPO/EPPO_MEMBERS/phytoreg/eu_ texts/2006-063-EC-e.pdf.

Anonymous (2010). The seed potato (Scotland) regulation. http:// www.legislation.gov.uk/ssi/2010/71/made/data.pdf.

Anonymous (2010c). Rulebook on phytosanitary measures for detection, Prevention of spreading and control of potato brown rot caused by bacterium Ralstonia solanacearum (Smith) Yabuuchi et al.*.

Anonymous (2016). The seed potato regulations Northern Ireland. http://www.legislation.gov.uk/nisr/2016/190 /pdfs/nisr_20160190_en.pdf.

Anonymous (2017). Statistical Review of Northern Ireland Agriculture. http://www.daerani.gov. $\mathrm{uk} / \mathrm{sites} / \mathrm{default} /$ files/publications/daera/Stats $\% 20$ Review\%202017\%20final.pdf.

Bastas, K. K., Hekimhan, H., Maden, S., \& Tor, M. (2009). First report of bacterial stalk and head rot disease caused by Pectobacterium atrosepticum on sunflower in Turkey. Plant Diseases, 93, 1352.

Bdliya, B. S., Langerfeld, E., \& Rudolph, K. (2004). A modified crystal violet pectate (CVP) medium for detection and isolation of soft rot Erwinia spp. from plant materials. Journal of Plant Diseases and Protection, 111, 506-515.

Bhat, K. A., Masood, S. D., Bhat, N. A., Ashraf Bhat, M., Razvi, S. M., Mir, M. R., Akhtar, S., Wani, N., \& Habib, M. (2010). Current status of postharvest soft rot in vegetables: Review. Asian Journal of Plant Sciences, 9, 200-208.

Bourke, P. M. (1966). A contribution to the early history of black leg disease of the potato. Journal of the Department of Agriculture, Ireland, 63, 103.

Brady, C. L., Cleenwerck, I., Denman, S., Venter, S. N., Rodríguez-Palenzuela, P., Coutinho, T. A., \& De Vos, P. (2012). Proposal to reclassify Brenneria quercina (Hildebrand \& Schroth 1967) Hauben et al. 1999 into a novel genus, Lonsdalea gen. nov., as Lonsdalea quercina comb. nov., descriptions of Lonsdalea quercina subsp. quercina comb. nov., Lonsdalea quercina subsp. iberica subsp. nov. and Lonsdalea quercina subsp. britannica subsp. nov., emendation of the description of the genus Brenneria, reclassification of Dickeya dieffenbachiae as Dickeya dadantii subsp. dieffenbachiae comb. nov., and emendation of the description of Dickeya dadantii. International Journal of Systematic and Evolutionary Microbiology, 62, 1592-1602.

Buttimer, C., Hendrix, H., Lucid, A., Neve, H., Noben, J. P., Franz, K., O’Mahony, J., Lavigne, R., \& Coffey, A. (2018). Novel N4 - Like Bacteriophages of Pectobacterium atrosepticum. Pharmaceticals, 11. https://doi.org/10.3390/ph11020045.

Cariddi, C., \& Sanzani, S. M. (2013). A severe outbreak of bacterial lettuce soft rot caused by Pectobacterium carotovorum subsp. carotovorum in Apulia (Italy). Journal of Plant Pathology, 95, 441-446.

Crowhurst, R. N., \& Wright, P. J. (1998). Subspecies of Erwinia carotovora causing blackleg of potato in Pukekohe and Pukekawa and their survival in soils. New Zealand Potato Bulletin, 109, 20-22. 
Czajkowski, R., Pérombelon, M., Jafra, S., Lojkowska, E., Potrykus, M., van der Wolf, J., \& Sledz, W. (2015). Detection, identification and differentiation of Pectobacterium and Dickeya species causing potato blackleg and tuber soft rot: a review. Annals of Applied Biology, 166, $18-38$.

Darasse, A., Priou, S., Kotoujansky, A., \& Bertheau, Y. (1994). PCR and restriction fragment length polymorphism of a pel gene as a tool to identify Erwinia carotovora in relation to potato diseases. Applied Environmental Microbiology, 60, 1437-1443.

de Boer, S. H., Li, X., \& Ward, L. J. (2012). Pectobacterium spp. associated with bacterial stem rot syndrome of potato in Canada. Phytopathology, 102, 937-947.

de Haan, E. G., Dekker-Nooren, T. C. E. M., van den Bovenkamp, G. W., Speksnijder, A. G. C. L., van der Zouwen, P. S., \& van der Wolf, J. M. (2008). Pectobacterium carotovorum subsp. carotovorum can cause potato blackleg in temperate climates. European Journal of Plant Pathology, 122, 561-569.

de Werra, P., Bussereau, F., \& Keiser, A. (2015). First report of potato blackleg caused by Pectobacterium carotovorum subsp. brasiliense in Switzerland. Plant Disease, 99, 551.

Dees, M. W., Lebecka, R., Perminow, J. I., Czajkowski, R., Grupa, A., Motyka, A., Zoledowska, S., Śliwka, J., Łojkowska, E., \& Brurberg, M. B. (2017a). Characterization of Dickeya and Pectobacterium strains obtained from diseased potato plants in different climatic conditions of Norway and Poland. European Journal of Plant Pathology, 148, 839-851.

Dees, M. W., Lysoe, E., Rossmann, S., Perminow, J., \& Brurberg, M. B. (2017b). Pectobacterium polaris sp. nov., isolated from potato (Solanum tuberosum). International Journal of Evolutionary and Systematic Microbiology, 67, 5222-5229.

Elphistone, J. (2016a). Blackleg survey - English and welsh seed crops 2013 - 2015. Final report. https://potatoes.ahdb.org. $\mathrm{uk} /$ sites/default/files/publication_upload/R475\%20Final\%20 Report\%20for\%20publication.pdf.

Elphistone, J. (2016b). Blackleg survey samples. Final report. http://potatoes.ahdb.org.uk/sites/default/files/publication upload $/ 2016 \% 20$ monitoring $\% 20$ stocks $\% 20$ of $\% 20 \mathrm{a} \% 20$ single $\% 20$ variety.pdf.

EPPO (2017). EPPO A2 List of pests recommended for regulation as quarantine pests. http://www.eppo. int/QUARANTINE/listA2.htm.

Frechon, D., Exbrayat, P., Helias, V., \& 7 other authors. (1998). Evaluation of a PCR kit for the detection of Erwinia carotovora subsp. atroseptica on potato tubers. Potato Research, 41, 163-173.

Gans, P. T., Jellis, G. J., Little, G., Logan, C., \& Wastie, R. L. (1991). A comparison of methods to evaluate the susceptibility of potato cultivars to blackleg (caused by Erwinia carotovora subsp. atroseptica) in the field at different sites. Plant Pathology, 40, 238-248.

Gardan, L., Gouy, C., Christen, R., \& Samson, R. (2003). Elevation of three subspecies of Pectobacterium carotovorum to species level: Pectobacterium atrosepticum sp nov., Pectobacterium betavasculorum sp nov. and Pectobacterium wasabiae sp nov. International Journal of Systematic and Evolutionary Microbiology, 53, 381-391.

Golanowska, M., \& Łojkowska, E. (2016). A review on Dickeya solani, a new pathogenic bacterium causing loss in potato yield in Europe. BioTechnologia, 97, 109-127.
Hauben, L., Moore, E. R., \& Vauterin, L. (1998). Phylogenetic position of phytopathogens within the Enterobacteriaceae. Systemic and Applied Microbiology, 21, 384-397.

Hossain, M. (1986). Survey of Northern Ireland seed potato stocks for assessment of bacterial soft rot. Bangladesh Journal of Agriculture, 11, 65-72.

Hossain, M., \& Logan, C. (1983). A comparison of inoculation methods for determining potato cultivar reaction to black leg. Annals of Applied Biology, 103, 63-70.

Khayi, S., Cigna, J., Chong, T. M., Quetu-Laurent, A., Chan, K. G., Helias, V., \& Faure, D. (2016). Transfer of the potato plant isolates of Pectobacterium wasabiae to Pectobacterium parmentieri sp. nov. International Journal of Systematic and Evolutionary Microbiology, 66, 5379-5383.

Kimura, M. (1980). A simple method for estimating evolutionary rates of base substitutions through comparative studies of nucleotide sequences. Journal of Molecular Evolution, 16, 111-120.

Laurila, J., Ahola, V., Lehtinen, A., Joutsjoki, T., Hannukkala, A., Rahkonen, A., \& Pirhonen, M. (2008). Characterization of Dickeya strains isolated from potato and river water samples in Finland. European Journal of Plant Pathology, 122, 213225.

Laurila, J., Hannukkala, A., \& Nykyri, J. (2010). Symptoms and yield reduction caused by Dickeya spp. strains isolated from potato and river water in Finland. European Journal of Plant Pathology, 126, 249-262.

Li, X., Ma, Y., Liang, S., Tian, Y., Yin, S., Xie, S., \& Xie, H. (2018). Comparative genomics of 84 Pectobacterium genomes reveals the variations related to a pathogenic lifestyle. BMC Genomics, 19, 889-911.

Logan, C. (1963). A selective medium for the isolation of soft rot coliforms from soil. Nature, 199, 623.

Logan, C. (1966). Simple method of differentiating Erwinia carotovora variety 'Atroseptica' from E. carotovora and E. carotovora variety 'Aroideae'. Nature, 212, 1584-1585.

Logan, C. (1968). The survival of the potato blackleg pathogen over winter. Records, Agricultural Research, Ministry of Agriculture of Northern Ireland, 17, 115-121.

Logan, C. (1984). Potato black leg. Annual report on the research and technical work of the department of agriculture for Northern Ireland., 203-204.

Logan, C., O’Neill, R., McGrane, P., \& Little, G. (1987). Methods for detection of the blackleg, ring rot and gangrene pathogens in potato nuclear stock mother tubers and plantlets. EPPO Bulletin, 17, 17-23.

Ma, B., Hibbing, M. E., Kim, H. S., Reedy, R. M., Yedidia, I., Breuer, J., Breuer, J., Glasner, J. D., Perna, N. T., Kelman, A., \& Charkowski, A. O. (2007). Host range and molecular phylogenies of the soft rot enterobacterial genera Pectobacterium and Dickeya. Phytopathology, 97, 1150-1163.

Mansfield, J., Genin, S., Magori, S., Citovsky, V., Sriariyanum, M., Ronald, P., Dow, M., Verdier, V., \& Beer, S. V. (2012). Top 10 plant pathogenic bacteria in molecular plant pathology. Molecular Plant Pathology, 13, 614-629.

Moraes, A. J. G., Souza, E. B., Mariano, R. L. R., Silva, A. M. F., Lima, M. B., Peixoto, A. R., \& Gama, M. A. S. (2017). First report of Pectobacterium aroidearum and Pectobacterium carotovorum subsp. brasiliensis causing soft rot of Cucurbita pepo in Brazil. Plant Disease, 101, 379. 
Moretti, C., Fakhr, R., Cortese, C., de Vos, P., Cerri, M., Geagea, L., Cleenwerck, I., \& Buonaurio, R. (2016). Pectobacterium aroidearum and Pectobacterium carotovorum subsp. carotovorum as causal agents of potato soft rot in Lebanon. European Journal of Plant Pathology, 144, 205-211.

Naas, H., Sebaihia, M., Orfei, B., Rezzonico, F., Buonaurio, R., \& Moretti, C. (2018). Pectobacterium carotovorum subsp. brasiliense and Pectobacterium carotovorum subsp. carotovorum as causal agents of potato soft rot in Algeria. European Journal of Plant Pathology. https://doi. org/10.1007/s10658-018-1438-3.

Nabhan, S., De Boer, S.H., Maiss, E., \& Wydra, K. (2013). Pectobacterium aroidearum sp. nov., a soft rot pathogen with preference for monocotyledonous plants. International Journal of Systematic and Evolutionary Microbiology, 61, 498-508.

Nunes Leite, L., de Haan, E. G., Krijger, M., Kastelein, P., van der Zouwen, P. S., van den Bovenkamp, G. W., Tebaldi, N. D., \& van der Wolf, J. M. (2014). First report of potato blackleg caused by Pectobacterium carotovorum subsp. brasiliensis in the Netherlands. New Disease Reports, 29, 24.

O'Neil, R., \& Logan, C. (1975). A comparison of various selective isolation media for their efficiency in the diagnosis and enumeration of soft rot coliform bacteria. Journal of Applied Bacteriology, 39, 139-146.

Onkendi, E. M., \& Moleleki, L. N. (2014). Characterization of Pectobacterium carotovorum subsp. carotovorum and brasiliense from diseased potatoes in Kenya. European Journal of Plant Pathology, 139, 557-556.

Oztruk, M., Aksoy, H. M., Potrykus, M., \& Lojkowska, E. (2018). Genotypic and phenotypic variability of Pectobacterium strains causing blackleg and soft rot on potato in Turkey. European Journal of Plant Pathology, 152, 143-155.

Parkinson, N., Stead, D., Bew, J., Heeney, J., Tsror Lahkim, L., \& Elphinstone, J. (2009). Dickeya species relatedness and clade structure determined by comparison of recA sequences. International Journal of Systematic and Evolutionary Microbiology, 59, 2388-2393.

Parkinson, N., DeVos, P., Pirhonen, M., \& Elphinstone, J. (2014). Dickeya aquatica sp. nov., isolated from waterways. International Journal of Systematic and Evolutionary Microbiology, 64, 2264-2266.

Peltzer, S., \& Sivasithamparam, K. (1985). Soft - rot erwinias and stem rots in potatoes. Australian Journal of Experimental Agriculture, 25, 693-696.

Pérombelon, M. C. M. (2002). Potato diseases caused by soft rot erwinias: An overview of pathogenesis. Plant Pathology, 51, $1-12$.

Pérombelon, M. C. M., \& Kelman, A. (1980). Ecology of soft rot Erwinias. Annual Review of Phytopathology, 18, 361-387.

Pethybridge, G. H., \& Murphy, P. A. (1911). A bacterial disease of the potato Plant in Ireland and the organism causing it. Proceedings of the Royal Irish Academy, 29(Section B), 1-37.

Potrykus, M., Golanowska, M., Śledź, W., Zoledowska, S., Motyka, A., Kolodziejska, A., Butrymowicz, J., \& Łojkowska, E. (2016). Biodiversity of Dickeya spp. isolated from potato plants and water sources in temperate climate. Plant Disease, 100, 408-417.

Pritchard, L., Humphris, S., Saddler, G. S., Parkinson, N. M., Bertrand, V., Elphinstone, J. G., \& Toth, I. K. (2013). Detection of phytopathogens of the genus Dickeya using a
PCR primer prediction pipeline for draft bacterial genome sequences. Plant Pathology, 62, 587-596.

Proudfoot, K. G., \& Mccallum, D. J. (1961). Seed potato production in Northern Ireland. European Potato Journal, 4, 330 340 .

Rhodes, D. J., \& Logan, C. (1986). Effects of fluorescent pseudomonads on the potato blackleg syndrome. Annals of Applied Biology, 108, 511-518.

Rhodes, D. J., \& Logan, C. (1987). A method for selecting fluorescent pseudomonads inhibitory to seed tuber decay. Potato Research, 30, 603-611.

Samson, R., Legendre, J. B., Christen, R., Fischer-Le Saux, M., Achouak, W., \& Gardan, L. (2005). Transfer of Pectobacterium chrysanthemi (Burkholder et al. 1953) Brenner et al. 1973 and Brenneria paradisiaca to the genus Dickeya gen. nov. as Dickeya chrysanthemi comb. nov. and Dickeya paradisiaca comb. nov. and delineation of four novel species, Dickeya dadantii sp. nov., Dickeya dianthicola sp. nov., Dickeya dieffenbachiae sp. nov. and Dickeya zeae sp. nov. International Journal of Systematic and Evolutionary Microbiology, 55, 1415-1427.

Sarfraz, S., Riaz, K., Oulghazi, S., Cigna, J., Sahi, S. T., Khan, S. H., \& Faure, D. (2018). Pectobacterium punjabense sp. nov., isolated from blackleg symptoms of potato plants in Pakistan. International Journal of Systematic and Evolutionary Microbiology, 68, 3551-3556.

Shirshikov, F. V., Korzhenkov, A. A., Miroshnikov, K. K., Kabanova, A. P., Barannik, A. P., \& Ignatov, A. N. (2018). Draft genome sequences of new genomospecies "Candidatus Pectobacterium maceratum" strains, which cause soft rot in plants. Genome Announcment, 6, e00260-e00218.

Skelsey, P., Elphinstone, J. G., Saddler, G. S., \& Wale, S. J. (2016). Spatial analysis of blackleg-affected seed potato crops in Scotland. Plant Pathology, 65, 570-576.

Skelsey, P., Humphris, S. N., Campbell, E. J., \& Toth, I. K. (2018). Threat of establishment of non-indigenous potato blackleg and tuber soft rot pathogens in Great Britain under climate change. PLoS One, 12. https://doi.org/10.1371/journal. pone.0205711.

Stommel, J. R., Goth, R. W., \& Haynes, K. G. (1996). Pepper (Capsicum annuum) soft rot caused by Erwinia carotovora subsp. atroseptica. Plant Disease, 80, 1109-1112.

Tamura, K., Nei, M., \& Kumar, S. (2004). Prospects for inferring very large phylogenies by using the neighbor-joining method. Proceedings of National Academy of Sciences of the United States of America, 101, 11030-11035.

Tian, Y., Zhao, Y., Yuan, X., Yi, J., Fan, J., Xu, Z., Hu, B., De Boer, S. H., \& Li, X. (2016). Dickeya fangzhongdai sp. nov., a plant-pathogenic bacterium isolated from pear trees (Pyrus pyrifolia). International Journal of Systematic and Evolutionary Microbiology, 66, 2831-2835.

Toth, I. K., Bell, K. S., Holeva, M. C., \& Birch, P. R. (2003). Soft rot erwiniae: From genes to genomes. Molecular Plant Pathology, 1, 17-30.

Toth, I. K., van der Wolf, J. M., Saddler, G., Łojkowska, E., Hélias, V., Pirhonen, M., Tsror, L., \& Elphinstone, J. G. (2011). Dickeya species: An emerging problem for potato production in Europe. Plant Pathology, 60, 385-399.

Toth, I. K., Humphris, S., Brierley, J., Skelsey, P., Saddler, G., Cahill, G., \& Wale, S. (2016). Routes of blackleg 
contamination of high grade potato seed stocks by Pectobacterium species. http://www.potatoes.ahdb.org.uk.

van der Merwe, J. J., Coutinho, T. A., Korsten, L., \& van der Waals, J. E. (2010). Pectobacterium carotovorum subsp. brasiliensis causing blackleg on potatoes in South Africa. European Journal of Plant Pathology, 126, 175-185.

van der Wolf, J. M., Nijhuis, E. H., Kowalewska, M. J., Saddler, G. S., Parkinson, N., Elphinstone, J. G., Pritchard, L., Toth, I. K., Łojkowska, E., Potrykus, M., Waleron, M., de Vos, P., Cleenwerck, I., Pirhonen, M., Garlant, L., Helias, V., Pothier, J. F., Pflüger, V., Duffy, B., Tsror, L., \& Manulis, S. (2014). Dickeya solani sp. nov., a pectinolytic plant pathogenic bacterium isolated from potato (Solanum tuberosum). International Journal of Systematic and Evolutionary Microbiology, 64, 768-774.

van der Wolf, J. M., de Haan, E. G., Kastelein, P., Krijger, M., de Haas, B. H., Velvis, H., Mendes, O., Kooman-Gersmann, M., \& van der Zouwen, P. S. (2017). Virulence of Pectobacterium carotovorum subsp. brasiliense on potato compared with that of other Pectobacterium and Dickeya species under climatic conditions prevailing in the Netherlands. Plant Pathology, 66, 571-583.

Waleron, M., Misztak, A., Franczuk, M., Jonca, J., Wielgomas, B., Mikicinski, A., Popovic, T., \& Waleron, K. (in press). Pectobacterium zantedeschiae sp. nov. a new species of a soft rot pathogen isolated from Calla lily (Zantedeschia spp.). Systematic and Applied Microbiology.
Waleron, M., Waleron, K., Podhajska, A. J., \& Łojkowska, E. (2002). Genotyping of bacteria belonging to the former Erwinia genus by PCR-RFLP analysis of a recA gene fragment. Microbiology, 148, 583-595.

Waleron, M., Waleron, K., \& Łojkowska, E. (2013). Occurrence of Pectobacterium wasabiae in potato field samples. European Journal of Plant Pathology, 137, 149-158.

Waleron, M., Misztak, A., Waleron, M., Franczuk, M., Wielgomas, B., \& Waleron, K. (2017). Transfer of Pectobacterium carotovorum subsp. carotovorum strains isolated from potatoes grown at high altitudes to Pectobacterium peruviense sp. nov. Systematic and Applied Microbiology, 41, 85-93.

Waleron, M., Misztak, A., Jonca, J., Furmaniak, M., Waleron, M. M., \& Waleron, K. (2019). First report of "Candidatus Pectobacterium maceratum" causing soft rot of potato in Poland. Plant Disease. https://doi.org/10.1094/PDIS-10-181849-PDN.

Wastie, R. S., Jellis, G. J., Lapwood, D. H., Logan, C., Little, G., \& Phillips, M. S. (1988). Assessing potato cultivars for resistance to tuber soft rot (Erwinia carotovora subsp. atroseptica) at four test centres in the UK. Potato Research, 31, 67-72.

Winslow, C. E. A., Broadhurst, J., Buchanan, R. E., Krumwiede, C., Rogers, L. A., \& Smith, G. H. (1920). The families and genera of the bacteria. Final report of the Committee of the Society of American Bacteriologists on characterization and classification of bacterial types. Journal of Bacteriology, 5, 191-229. 